\title{
ФОРМУВАННЯ ІНТЕРАКТИВНИХ КОНФІГУРАЦІЙ СТАНУ РИНКОВОГО СЕРЕДОВИЩА
}

\section{Владимир Байгушев \\ ФОРМИРОВАНИЕ ИНТЕРАКТИВНЫХ КОНФИГУРАЦИЙ СОСТОЯНИЯ РЫНОЧНОЙ СРЕДЫ}

\author{
Vladimir Baigushev \\ CREATING INTERACTIVE CONFIGURATIONS \\ OF THE STATE OF THE MARKET ENVIRONMENT
}

Головна ідея статті полягає в розробленні підходу до процесу аналізу ринкового середовища на основі наявних його інтерактивних станів із подальшою кількісною оцінкою отриманої конфігурації такого середовища як об'єкта аналізу. В умовах зростаючої невизначеності ринкового середовища діагностика причин $і$ майбутнього стану ринку має особливу актуальність. Наведено схеми методології процесу аналізу та оцінки стану конкурентних сил ринкового середовища в умовах невизначеності. Розроблено підсумкову таблицю оиінки стану основних параметрів зовнішнього середовища в сегменті галузі чорної металургї Украӥни - виробництво сталі та сталевого (чорного) металопрокату за 2014-2018 роки. На основі розробленого підходу наведено показники зміни виробниитва сталі та прокату в сегменті за однакові періоди 2018-2019 років. Інтерактивний аналіз усього обсягу даних за 2014-2019 роки дало змогу зробити висновок про перехід ринкового середовища сегмента у відносно стабільний стан.

Ключові слова: аналіз; ринкове середовище; інтерактивність; конкурениія; ринок; невизначеність; параметр; сегмент галузі.

Рис.: 2. Табл.: 7. Бібл.: 11.

Главная идея статьи заключается в разработке подхода к прочессу анализа рыночной среды на основе имеющихся её интерактивных состояний с последующей количественной оценкой полученной конфигурачии данной среды как объекта анализа. В условиях растущей неопределённости рыночной среды диагностика причин и будущего состояния рынка имеет особую актуальность. Приведены схемы методологии процесса анализа и оценки состояния конкурентных сил рыночной среды в условиях неопределённости. Разработана итоговая таблица оченки состояния основных параметров внешней среды в сегменте отрасли чёрной металлургии Украины - производство стали и стального (чёрного) металлопроката за 2014-2018 годы. На основе разработанного подхода приведены показатели изменения производства стали и проката в сегменте за одинаковые периоды 2018-2019 годов. Интерактивный анализ всего объёма данных за 2014-2019 годы позволил сделать вывод о переходе рыночной среды сегмента в относительно-стабильное состояние.

Ключевые слова: анализ; рыночная среда; интерактивность; конкуренция; рынок; неопределённость; параметр; сегмент отрасли.

Рис.: 2. Табл.: 7. Библ.: 11.

The main idea of the article is to develop an approach to the process of analyzing the market environment based on its existing interactive States, followed by a quantitative assessment of the resulting configuration of this environment as an object of analysis. In the growing uncertainty of the market environment, diagnostics of the causes and future state of the market is particularly relevant. Schemes of methodology for analyzing and evaluating the state of competitive forces in the market environment under conditions of uncertainty are given. Based on the diagrams summary table assessment of the basic parameters of the external environment in the segment of ferrous metallurgy of Ukraine - steel production and steel (black) metal for 2014-2018. Based on the developed approach, the indicators of changes in the production of steel and rolled products in the segment for the same periods of 2018-2019 are presented. An interactive analysis of the entire volume of data for 2014-2019 allowed us to conclude that the market environment of the segment has moved to a relatively stable state.

Keywords: analysis; market environment; interactivity; competition; market; uncertainty; parameter; segment of the industry.

Fig.: 2. Table: 7. References: 11.

JEL Classification: D8; D2

Постановка проблеми. Формування конкурентної стратегії для господарюючих суб'єктів у невизначеному стані ринкового середовища є науковою і практичною проблемою сучасної економіки. Дослідженням у цій галузі присвячені роботи Р. Акоффа, М. Портера, П. Сенге, В. Стівенсона, Б. Файфера, В. Агафонова, В. Абрамова та інших учених-економістів. При цьому невирішеними як у теоретичному, так і у практичному плані $є$ проблеми, що виникають при конкурентному управлінні об'єднаними корпоративними структурами (далі ОКС) в умовах невизначеності. У разі виникнення умов невизначеності ринку концептуальною базою формування конкурентних стратегій ОКС $\epsilon$ 
аналіз ринкового середовища 3 дослідженням діючих конкурентних сил, структури галузі, базових умов існування і функціонування галузі. Уперше за допомогою системного підходу формування конкурентної стратегії ОКС в умовах невизначеності дослідив М. Портер у [8, с. 600]. Фундаментом дослідження цього автора є створення альтернативних галузевих сценаріїв майбутнього стану та ведення бізнесу в галузі. Цьому завданню відповідає процес створення сценаріїв зовнішнього середовища, що визначають умови господарювання ОКС. Ученому належить розробка визначальних етапів при розробці галузевих сценаріїв [8, с. 604]. При цьому науковець особливо виділяє творчий підхід для вирішення поставленого завдання. Особливе значення в роботі надається невирішеній проблемі, що виникає під час оцінювання інформаційного масиву інформації, його об'єктивній оцінці, виділення основних діючих факторів невизначеності і прийняття рішень для розробки конкурентної стратегії. Поява нових публікацій спрямована на вирішення цих проблем.

Аналіз останніх досліджень і публікацій. У роботі [10] автори стверджують, що характерною рисою сучасного менеджменту господарської організації $є$ посилення уваги до стратегічних аспектів управління. Таке рішення пов'язане з проблемами постійного розвитку організації відповідно до динамічно мінливих умов зовнішнього ринкового середовища. Вироблення стратегії в таких умовах повинно враховувати швидкість адаптації стану підприємства після кожних істотних змін в економіці. У статті [11] наголошується, що оцінювання ефективності бізнес-систем організацій у різних галузях істотно ускладняється за наявності невизначеності зовнішнього середовища. У [11] розглянуто питання обліку декількох факторів зовнішнього середовища та керованих внутрішніх факторів підприємства, що дозволяє підвищити об'єктивність прийнятих рішень. Багатокритеріальний підхід при вирішенні таких завдань в умовах невизначеності вимагає розробки нових підходів для їх вирішення. У своїй роботі Н. Незаметдинов [6] наводить постановку завдань вибору ефективних рішень в умовах невизначеного зовнішнього середовища. Особливістю цього дослідження є визначення оцінки ефективності прийнятих рішень, з урахуванням керованих і некерованих факторів. У свою чергу, Н. Плеханов [7] на підставі методу SWOTаналізу дослідив вплив зовнішнього середовища на прийняття стратегічних рішень. Для цього вироблено формування таких матриць зовнішнього середовища: «сильні сторони загрози», «сильні сторони - можливості», потім автор сформував матрицю ефективності. Маючи у своєму розпорядженні матрицю ефективності за допомогою того чи іншого принципу ефективності можна визначити найбільш переважне рішення для діяльності в умовах невизначеності зовнішнього середовища. У статті [1] О. Глебова, О. Мельникова аналізують питання, пов'язані з оцінкою ризиків підприємства і наголошують, що найважливішу роль у цьому аспекті відіграють фактори невизначеності. Проаналізовано стан невизначеності, пов'язаної з браком інформації про стан зовнішнього середовища для господарської діяльності окремого підприємства. Для пошуку оцінок ризику в умовах невизначеності використовуються критерії: максимакса, Вальда, Севіджа, Гурвіца, БаєсаЛапласа. У статті [2] проаналізовано питання стратегічного аналізу зовнішнього середовища організацій. Наведено проблемні питання стратегічного управління для умов невизначеності в теперішній час. Особливу увагу у статті приділено структурі й факторам зовнішнього середовища, а також взаємозв'язку між формуванням стратегії і рівнем невизначеності зовнішнього середовища. Потенційний успіх підприємства, на погляд О. Лящук [5], буде багато в чому залежати від точності визначення різних параметрів економічного середовища. В умовах невизначеності особливого значення набуває прогноз їх подальших змін. Залежно від об'єктивності та похибки аналізу економічного середовища визначається ефективність загальної стратегії підприємства. О. Лящук [5] зауважує, що існує величезна безліч факторів, а відобразити їх абсолютно всі неможливо. В умовах не- 
ТЕОРЕТИЧНІ ПРОБЛЕМИ РОЗВИТКУ НАЦІОНАЛЬНОЇ ЕКОНОМІКИ

визначеності кількість і сила впливу цих факторів буде дуже змінюватися. Ефективність аналізу найбільш значущих факторів визначає величину ймовірності прийняття ефективних рішень при стратегічному плануванні. У статті [3] досліджено вплив нестабільності зовнішнього середовища на господарську діяльність підприємств. Як методи дослідження застосовані матриця І. Ансоффа і матриця Р. Дункан. Водночас К. Заніна, Ю. Бородач розробили метод, який об'єднує обидва підходи. Розгляд наведених публікацій показує, що є безліч факторів, що визначають досягнення об'єктивної оцінки стану ринку в умовах невизначеності. При цьому дослідження проводяться без урахування кількісної оцінки наявних факторів, відділення істотних факторів від факторів несуттєвих, а також аналізу взаємодії необхідних факторів.

Виділення недосліджених частин загальної проблеми. Аналіз перерахованих публікацій свідчить, на наш погляд, що головною проблемою у процесі аналізу ринкового середовища в умовах невизначеності є відсутність замкнутої системи дослідження в процесі оцінювання факторів виникнення, взаємодії, розвитку і закінчення дії умов невизначеності, оскільки важливою характеристикою умов невизначеності $є$ тимчасовий інтервал іiі дії. Після завершення їхньої дії зовнішнє середовище, з великою часткою ймовірності, повертається в умови визначеності й відносної стабільності. Вирішенню зазначеної проблеми за допомогою інтерактивного підходу і присвячена ця стаття.

Мета статті. Дослідити формування інтерактивних конфігурацій ринкового середовища в разі виникнення стану невизначеності та обгрунтувати рішення для її оцінки.

Виклад основного матеріалу. Стан «невизначеності ринкового середовища» відрізняється від стану «визначеності ринкового середовища» насамперед істотною кількісною зміною таких характеристик: видами і наявністю істотних і несуттєвих факторів; значеннями факторів і величинами діапазонів коливань істотних факторів; моментами часу виникнення та припинення існування невизначеного стану ринкового середовища, в якому веде бізнес господарська організація. Особливо необхідно зазначити, що характер таких змін не має певних функціональних залежностей і має випадковий характер. Ці процеси характеризуються як випадкові процеси й вивчаються в кількісному плані, за допомогою теорії ймовірності і статистичного аналізу. Розділ теорії ймовірності і статистичного аналізу, присвячений методам обробки та використання статистичних даних для вивчення випадкових процесів в економіці, пов'язаний із певними обмеженнями і допущеннями. Головними 3 них є: випадкові значення, що визначають стан обраних параметрів в економічному процесі $\mathrm{X}\left(\mathrm{x}_{1}, \mathrm{x}_{2} \ldots \mathrm{x}_{\Gamma}\right)$, мають значну перевагу за величиною $\mathrm{i}$ достовірністю в порівнянні 3 випадковими значеннями параметра шуму $\mathrm{N}\left(\mathrm{n}_{1}, \mathrm{n}_{2} \ldots \mathrm{n}_{\mathrm{r}}\right)$; статистичної оцінки значень будь-яких інших параметрів, крім обраних, що визначають стан економічного процесу X (t), не потрібно; за вибраний інтервал часу випадкові значення, що визначають стан параметрів економічного процесу $\mathrm{X}\left(\mathrm{x}_{1}, \mathrm{x}_{2} \ldots \mathrm{x}_{\Gamma}\right), \epsilon$ стаціонарними (незалежними від часу); випадкові значення показників, що визначають стан параметра $\mathrm{X}\left(\mathrm{x}_{1}, \mathrm{x}_{2} \ldots \mathrm{x}_{\Gamma}\right)$, залежать від числових характеристик визначених законів розподілу відповідно до наявних даних; випадкові значення економічного параметра визначаються (у цьому дослідженні) статистичними моментами вибіркової сукупності, а саме: початковий момент або середнє арифметичне, початковий момент зважений за частотами або середньо зважене за частотою арифметичне, інтервал змін з урахуванням крайніх значень. Вплив мінливих факторів ринкового середовища, які визначають зовнішній вплив на об’єднану корпоративну структуру (далі ОКС), є визначальним і вимагає всеосяжного аналізу не тільки методами теорії ймовірності, а й застосування методів теорії економічного аналізу. При невизначеному стані ринкового середовища організації бізнесу, яка бажає продовжувати господарську діяльність, повинна приймати рішення, які забезпечать іiі ефективне існування в умовах конкуренції і невизначеності. При такому невизначеному 
стані ринкового середовища продовжують вести бізнес конкуренти, які мають аналогічні цілі. Принциповою рисою цього дослідження є аналіз інтерактивних (інтерактивізм, від англ. interactive - взаємодія) станів галузі в умовах невизначеності. Під аналізом інтерактивного невизначеного стану галузі розуміється аналіз і оцінка ключових показників, що характеризують галузь у минулому, сьогоденні та прогнозованому майбутньому. Стан галузі в минулому і до дії факторів невизначеності відомі. Тому необхідно визначити стану галузі при такому діагнозі, як «невизначене», і в майбутньому при продовженні дії факторів невизначеності. Оцінка нового стану галузі починається з визначення факторів невизначеності, що викликали такий стан невизначеності галузі. На рис. 1 представлена методологія процесу аналізу галузі у вигляді замкнутої системи на основі інтерактивного конфігураційного підходу.

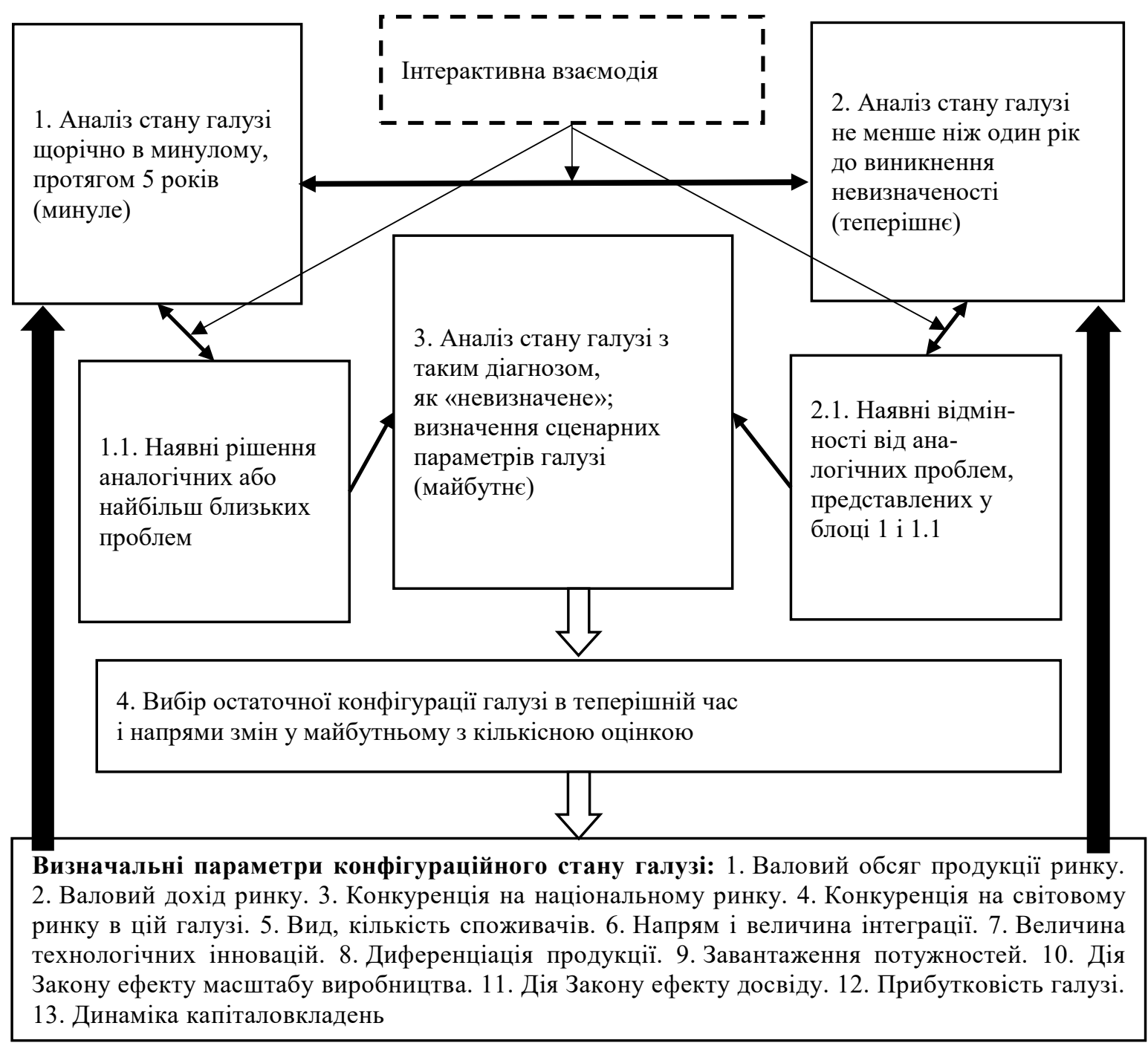

Рис. 1. Методологія проиесу аналізу для прийняття рімень

при невизначеному стані галузі на основі інтерактивного конфігураційного підходу

Джерело: розроблено автором.

Проміжок часу для проведення аналізу в минулому $-2,3,5$ років, сьогоденні - не менше ніж один рік із моменту діагностики виникнення дії факторів невизначеності. У процесі аналізу виробничо-економічного стану галузі використовуються дані: стану галузі щорічно в минулому, протягом 5 років; стану галузі не менше ніж один рік до виникнення невизначеності за кожен місяць, квартал, півріччя; стану галузі з таким діаг- 
ТЕОРЕТИЧНІ ПРОБЛЕМИ РОЗВИТКУ НАЦІОНАЛЬНОЇ ЕКОНОМІКИ

нозом, як «невизначене» та визначення конфігураційних (структурних) параметрів; інтерактивна взаємодія здійснюється постійно між блоками «1-2», «1-1.1», «2-2.1». Господарська діяльність ОКС може перебувати в одній або декількох галузях національного та міжнародних ринків.

Визначимо постановку головного завдання, як дослідження невизначеності ринкового середовища для формування конкурентної стратегії ОКС: визначення та об'єднання факторів у несуперечливі взаємовпливи для створення конфігурації ринкового середовища; аналіз ринкового середовища в кожній конфігурації; визначення конкурентних переваг для кожної конфігурації ринкового середовища при становленні й розвитку; прогноз поведінки конкурентів для кожної конфігурації ринкового середовища. Наявний теоретичний і практичний досвід формування конкурентних стратегій спирається на стратегічному досвіді мислення і аналізі при розробці стратегічних напрямів діяльності. Найважливішою рисою цього досвіду є представлення процесу створення конкурентних стратегій як замкнутого процесу, що складається з певних етапів. Ці етапи і формують дії організації для досягнення поставлених довготривалих і короткочасних цілей ОКС. Тому для розробки конкурентної стратегії ОКС в умовах невизначеності розробки тільки галузевого сценарію недостатньо. Підхід, що розробляється в цьому дослідженні, полягає у створенні замкнутого процесу й управління цим процесом, а саме конкурентного управління діяльністю ОКС в умовах невизначеності. Така постановка завдання передусім вимагає об'єктивного (незалежного від дослідника) і достовірного (заснованого на якісному і кількісному апаратурному оформленні) моніторингу аналізу зовнішнього середовища ведення бізнесу ОКС. Певні процедури аналізу зовнішнього середовища господарської діяльності полягають у наступному: оцінці масиву даних зовнішнього середовища, яка була прийнята до виникнення умов невизначеності; оцінці діючої стратегії для іiї продовження або вдосконалення; розробка та вибір принципово нової конкурентної стратегії з можливих альтернатив; визначення можливої майбутньої поведінки ОКС після завершення дії факторів невизначеності.

Першим етапом дій для здійснення перерахованих процедур в отриманні об'єктивного й достовірного аналізу зовнішнього середовища є: а) вибір і аналіз параметрів зовнішнього середовища до виникнення умов невизначеності або у стані визначеності; б) вибір об'єктивних і достовірних параметрів зовнішнього середовища 3 урахуванням стану цього об'єкта дослідження, як «невизначене»; в) відділення параметрів зовнішнього середовища мають принципове значення від параметрів досить важливих і несуттєвих; г) спосіб безперервного контролю надходить і наявної інформації, захищеної від помилок різних видів (суб’єктивізм, методична, апаратурна); д) пошук рішень за аналогією в минулому.

Аналіз ринкової галузі з дослідженням діючих конкурентних сил полягає в якісній (лідери, середняки, аутсайдери) оцінці стану конкуренції та кількісній оцінці восьми конкурентних сил, які діють у цьому ринковому середовищі і представлені на рис. 2. Найменування всіх восьми сил конкуренції і їхній характер взаємодії представлено на рис. 2.

Для проведення аналізу зовнішнього середовища відповідно до розглянутого вище підходу та вимог обрано сегмент галузі чорної металургії України - виробництво сталі та сталевого (чорного) металопрокату. Для виробництва чорного металопрокату використовується не менше ніж 83 \% всієї виплавленої сталі у світі. 


\begin{tabular}{|c|c|}
\hline $\begin{array}{l}\text { 1.1. Постачальники-споживачі (ресурсів) = } \\
\text { вартість суперечності цін, } \\
\text { 1-а конкурентна сила }\end{array}$ & $\begin{array}{l}\text { 2. Стан галузі та вплив } \\
\text { діючих сил конкуренції } \\
\text { в минулому, при невизна- }\end{array}$ \\
\hline $\begin{array}{l}\text { 1.2. Конкуренти ринку з (мінімальною - мак- } \\
\text { симальною) ціною на продукцію = вартість } \\
\text { суперечності, } \\
\text { 2-а конкурентна сила }\end{array}$ & $\begin{array}{l}\text { найбільш близькі стани } \\
\text { до виниклих умов невизна- } \\
\text { ченість }\end{array}$ \\
\hline $\begin{array}{l}\text { 1.3. Нові продавці (вартість входу-виходу) = } \\
\text { вартість суперечності, } \\
\text { 3-я конкурентна сила }\end{array}$ & $\nabla$ \\
\hline $\begin{array}{l}\text { 1.4. Продавці-покупці з (максимальною - } \\
\text { мінімальною) ціною на продукцію = вартість } \\
\text { суперечності, } \\
\text { 4-а конкурентна сила }\end{array}$ & $\begin{array}{l}\text { 3. Поточний стан галузі } \\
\text { та вплив діючих сил } \\
\text { конкуренції в поточному } \\
\text { стані }\end{array}$ \\
\hline $\begin{array}{l}\text { 1.5. Екологія-величина податку (максимальна } \\
\text { - мінімальна) = вартість суперечності } \\
\text { 5-а конкурентна сила }\end{array}$ & Н \\
\hline $\begin{array}{l}\text { 1.6. Держава-суб'єкти ринку ставка податку } \\
\text { (максимальна-мінімальні) = вартість суперечності } \\
\text { 6-а конкурентна сила }\end{array}$ & $\begin{array}{l}\text { діючих сил конкуренції } \\
\text { в майбутньому стані }\end{array}$ \\
\hline $\begin{array}{l}\text { 1.7. Товари-замінники-стандартний товар } \\
\text { (максимальні - мінімальні) ціни = вартість } \\
\text { суперечності, } \\
\text { 7-а конкурентна сила }\end{array}$ & $\begin{array}{l}\text { 5. Остаточна } \\
\text { конфігурація середо- }\end{array}$ \\
\hline $\begin{array}{l}\text { 1.8. Стейкхолдери з величиною частки (макси- } \\
\text { мального - мінімального) впливу = вартість су- } \\
\text { перечності, } \\
\text { 8-а конкурентна сила }\end{array}$ & $\begin{array}{l}\text { стану в галузі під } \\
\text { впливом інтерактивіз- } \\
\text { му. Вартість усіх } \\
\text { суперечностей }\end{array}$ \\
\hline
\end{tabular}

Рис. 2. Стан конкуренції та формування майбутнього стану ринкового середовища в умовах невизначеності

Джерело: розроблено автором.

У табл. 1 наведено обсяги виробництва сталі металургійними підприємствами України за період 2014-2018 років. Інтерактивний аналіз табл. 1 показує загальну тенденцію зниження виробництва сталі і стабілізації на рівні 21,0-21,3 млн т. Головною причиною такого падіння є політична ситуація в Україні.

Таблиця 1

Обсяги виробництва сталі металургійними підприємствами України за період 2013-2018 роки

\begin{tabular}{|l|c|c|c|c|c|}
\hline \multirow{2}{*}{ Параметр } & \multicolumn{5}{|c|}{ Рік } \\
\cline { 2 - 6 } & 2014 & 2015 & 2016 & 2017 & 2018 \\
\hline Валовий обсяг, млн тонн & 27,17 & 22,93 & 24,2 & 21,28 & 21,06 \\
\hline Зміни до попереднього року, \% & $-17,1$ & $-15,4$ & 5,2 & $-11,9$ & $-1,1$ \\
\hline
\end{tabular}

Примітка. У 2013 році вироблено сталі 32,8 млн тонн.

Джерело: [9]. 
ТЕОРЕТИЧНІ ПРОБЛЕМИ РОЗВИТКУ НАЦІОНАЛЬНОЇ ЕКОНОМІКИ

У табл. 2 наведено дані з виробництва, споживання і розрахунковий валовий дохід від продажу українського чорного сталевого металопрокату за діючими цінами. Величина споживання металопрокату власного виробництва всіма покупцями промисловості України на рівні 15-30 \%. Динаміка споживання переважно негативна і свідчить про відсутність розвитку машинобудування, суднобудування, автопрому, авіабудування та оборонного комплексу в країні.

Таблиця 2

Виробництво, споживання і валовий дохід

чорного сталевого металопрокату на Україні

\begin{tabular}{|l|c|c|c|c|c|}
\hline \multicolumn{2}{|c|}{ Найменування } & \multicolumn{5}{c|}{ Рік } \\
\cline { 2 - 7 } & 2014 * & 2015 & 2016 & 2017 & 2018 \\
\hline 1. Внутрішній ринок куплено, усього, млн т & 6,4 & 7,2 & 4,2 & 5,2 & 5,4 \\
\hline 2. Внутрішній ринок куплено імпорт, млн т & 1,7 & 3,1 & 1,3 & 1,4 & 1,3 \\
\hline 3. Експорт українського прокату, млн т & 18,4 & 15,9 & 18,5 & 14,6 & 14,3 \\
\hline 4. Усього вироблено прокату в Україні, млн т & 23,1 & 20,0 & 21,4 & 18,4 & 18,4 \\
\hline 5. Зміни виробництва прокату до попереднього року, \% & $-20,6$ & $-13,4$ & $+7,0$ & $-14,0$ & 0 \\
\hline $\begin{array}{l}\text { 6. Валовий дохід * від продажів українського чорного } \\
\text { металопрокату за період 2014-2018 років, млн дол. }\end{array}$ & 11018 & 9540 & 10207 & 8777 & 8777 \\
\hline
\end{tabular}

* - для розрахунку автором використовувалися середні ціни за рік металопрокату при експорті FOB і ціни внутрішнього ринку без ПДВ.

Примітка. У 2013 році вироблено прокату 29,1 млн тонн.

Джерело: [4; 9].

Інтерактивний аналіз табл. 2 показує загальну тенденцію зниження споживання металопрокату власного виробництва та імпорту на внутрішньому ринку України. Ознака інтерактивізму свідчить про взаємовплив виробництва і споживання цього виду продукції (табл. 1 і 2). Аналогічну тенденцію має експорт металопрокату і валовий дохід від продажів українського чорного металопрокату на національному та закордонному ринках. Вартість основних видів сталевого прокату українських виробників на національному ринку за даними прайс-листів (середні значення для лідерів з 1-го по 7-е місце) за 2014-2018 роки наведено в табл. 3. Дані табл. 3 показують стійку тенденцію зростання вартості прокату у вигляді гарячекатаного листа і сляба при невеликій волатильності будівельної арматури.

Таблиця 3

Вартість основних видів сталевого прокату українських виробників на національному ринку за даними прайс-листів

(середні значення для лідерів з 1-го по 7-е місие) за 2014-2018 роки

\begin{tabular}{|l|c|c|c|c|c|}
\hline \multirow{2}{*}{ Найменування продукції зі сталі } & \multicolumn{4}{|c|}{ Середня вартість прокату за роками, дол./т } \\
\cline { 2 - 6 } & 2014 & 2015 & 2016 & 2017 & 2018 \\
\hline 1. Сляб для переробки в прокат різних видів & 493 & 506 & 501 & 517 & 515 \\
\hline 2. Гарячекатаний лист, (далі Г/к) & 580 & 618 & 631 & 655 & 654 \\
\hline 3. Арматура будівельна & 563 & 571 & 567 & 560 & 566 \\
\hline Середня ціна металопрокату за рік & 545,3 & 565,0 & 566,3 & 577,3 & 578,3 \\
\hline
\end{tabular}

Джерело: [9].

У табл. 4 представлені ціни українських виробників металопрокату на експорт за основними видами за період 2014-2018 років.

За даними табл. 3, 4 у результаті інтерактивізму конкурентів на світовому ринку чорного металопрокату спостерігається зростання цін на 3-7 \%. 
Ціни украӥнських виробників металопрокату на експорт за основними видами за період 2014-2018 років (дол./m)

\begin{tabular}{|c|c|c|c|c|c|}
\hline \multirow[t]{2}{*}{ Найменування металопрокату } & \multicolumn{5}{|c|}{$\begin{array}{l}\text { Зміна цін за період 2014-2018 років, } \\
\text { діапазон цін / середнє значення }\end{array}$} \\
\hline & 2014 & 2015 & 2016 & 2017 & 2018 \\
\hline 1. Квадратна заготівля експорт, FОВ & $\begin{array}{c}470 \ldots 350 / \\
390\end{array}$ & $\begin{array}{c}290 \ldots 400 / \\
350\end{array}$ & $\begin{array}{c}395 \ldots 370 / \\
385 \\
\end{array}$ & $\begin{array}{c}360 \ldots 460 / \\
425\end{array}$ & $\begin{array}{c}360 \ldots 460 / \\
420\end{array}$ \\
\hline 2. Арма & $\begin{array}{c}510 . .340 / \\
420\end{array}$ & $\begin{array}{c}310 \ldots 400 / \\
380\end{array}$ & $\begin{array}{c}425 \ldots 410 / \\
418\end{array}$ & $\begin{array}{l}410 \ldots 490 / \\
460\end{array}$ & $\begin{array}{c}400 \ldots 450 / \\
435\end{array}$ \\
\hline $\begin{array}{l}\text { 3. Арматура будівельна, експорт Близький } \\
\text { Схід, CFR }\end{array}$ & $\begin{array}{c}560 \ldots 400 / \\
430\end{array}$ & $\begin{array}{c}325 \ldots 430 / \\
380\end{array}$ & $\begin{array}{c}450 \ldots 430 / \\
442\end{array}$ & $\begin{array}{l}410 \ldots 505 / \\
465\end{array}$ & $\begin{array}{l}395 \ldots 500 / \\
440\end{array}$ \\
\hline
\end{tabular}

FOB - товар вантажиться на корабель замовника.

CFR - товар доставляється до порту замовника (без вивантаження).

Джерело: [4].

У табл. 5 показана цінова конкуренція між українськими та китайськими виробниками на світових ринках.

Таблиця 5

Цінова конкуренція між українськими та китайськими виробниками металопрокату на національному та світовому ринку за 2014-2018 роки (дол. США / тонну)

\begin{tabular}{|c|c|c|c|c|c|}
\hline \multirow[t]{2}{*}{ Найменування металопрокату } & \multicolumn{5}{|c|}{$\begin{array}{l}\text { Зміна цін за період 2014-2018 років, } \\
\text { діапазон цін / середнє значення }\end{array}$} \\
\hline & 2014 & 2015 & 2016 & 2017 & 2018 \\
\hline 1. Г/к лист Китай, FOB & $\begin{array}{c}470 \ldots 530 / \\
500\end{array}$ & $\begin{array}{c}290 \ldots 345 / \\
320\end{array}$ & $\begin{array}{c}310 \ldots 440 / \\
370\end{array}$ & $\begin{array}{l}440 \ldots 500 / \\
460\end{array}$ & $\begin{array}{c}510 \ldots 620 / \\
565\end{array}$ \\
\hline 2. Г/к лист Україна, експорт FOB & $\begin{array}{c}470 \ldots 530 / \\
500\end{array}$ & $\begin{array}{c}280 \ldots 340 / \\
310\end{array}$ & $\begin{array}{l}300 \ldots 420 / \\
360\end{array}$ & $\begin{array}{l}425 \ldots 470 / \\
450\end{array}$ & $\begin{array}{c}480 \ldots 590 / \\
550\end{array}$ \\
\hline $\begin{array}{l}\text { 3. Г/к лист внутрішній ринок України } \\
\text { без НДС }\end{array}$ & $\begin{array}{l}500 \ldots 640 / \\
575\end{array}$ & $\begin{array}{l}400 \ldots 460 / \\
425\end{array}$ & $\begin{array}{l}350 \ldots 530 / \\
450\end{array}$ & $\begin{array}{l}530 \ldots 630 / \\
570\end{array}$ & $\begin{array}{c}630 \ldots 760 / \\
690\end{array}$ \\
\hline
\end{tabular}

Г/к - гарячекатаний.

FOB - товар вантажиться на корабель замовника.

Джерело: [4].

При відхиленнях у цінах не більше за 12 \% є деяка перевага українських виробників. Ця перевага заснована на значно вищих цінах цієї продукції на внутрішньому ринку України.

Аналіз стану сегмента галузі в «сьогоденні» для оцінки невизначеності (оцінка за схемою рис. 1, 2) наведені в табл. 6.

Таблиця 6

Показники параметрів оцінки стану: відносно-стабільні, $\pm 10 \%$ (C); нестабільно-залежні, $\pm 30 \%$ (3); невизначені, більш, $\pm 30 \%(H)$

\begin{tabular}{|c|c|c|c|c|}
\hline Найменування & Сталь, млн т. & Оцінка & Прокат, млн т. & Оцінка \\
\hline 2018 рік I півріччя & 10379 & \multirow{3}{*}{$\mathrm{C}$} & 9102 & \multirow{3}{*}{$\mathrm{C}$} \\
\hline 2019 рік I півріччя & 10897 & & 9393 & \\
\hline Зміна до попереднього періоду, \% & $+4,99$ & & $+3,2$ & \\
\hline 2018 рік 10 місяців & 17556 & \multirow{3}{*}{$\mathrm{C}$} & 15362 & \multirow{3}{*}{$\mathrm{C}$} \\
\hline 2019 рік 10 місяців & 17963 & & 15539 & \\
\hline Зміна до попереднього періоду, \% & $+2,32$ & & $+1,15$ & \\
\hline 2018 рік 11 місяців & 19214 & \multirow{3}{*}{$\mathrm{C}$} & 19842 & \multirow{3}{*}{$\mathrm{C}$} \\
\hline 2019 рік 11 місяців & 19288 & & 19948 & \\
\hline Зміна до попереднього періоду, \% & $+0,385$ & & $+0,53$ & \\
\hline
\end{tabular}

Джерело: [4; 9]. 
ТЕОРЕТИЧНІ ПРОБЛЕМИ РОЗВИТКУ НАЦІОНАЛЬНОЇ ЕКОНОМІКИ

Аналіз даних табл. 6 показує, що стан основних параметрів зовнішнього середовища в сегменті галузі чорної металургії України - виробництво сталі та сталевого (чорного) металопрокату переходить у відносно стабільний стан з оцінкою коливання ключових факторів не більше ( $\pm 10,0$ \%). У табл. 7 представлена підсумкова таблиця оцінки стану «минуле і майбутнє» основних параметрів ринкового середовища в сегменті галузі чорної металургії України - виробництво сталі та сталевого (чорного) металопрокату за період 2014-2018 роки («минуле») і 2020-2021 роки («майбутнє»). Ця таблиця інтегрально відображає наявну взаємодію (інтерактивізм) наведених 23 показників, що діють у сегменті галузі чорної металургії України - виробництво сталі та сталевого (чорного) металопрокату.

Таблиця 7

Підсумкова таблиця оцінки стану основних параметрів ринкового середовища в сегменті галузі чорної металургії України - виробництво сталі та сталевого (чорного) металопрокату за період 2014-2018 роки, «минуле і майбутнє»

\begin{tabular}{|c|c|c|c|c|}
\hline \multirow{2}{*}{$\begin{array}{c}\text { Найменування } \\
\text { параметрів }\end{array}$} & \multicolumn{3}{|c|}{$\begin{array}{l}\text { Показники параметрів оцінки стану: відносно } \\
\text { стабільні, } \pm 10 \% \text {, (оцінка С); Нестабільно залеж- } \\
\text { ні, } \pm 30 \text { \%, (оцінка 3); невизначені, більш, } \pm 30 \% \text {, } \\
\text { (оцінка Н) період (2014-2018) роки, «минуле» }\end{array}$} & \multirow{2}{*}{$\begin{array}{c}\text { Оцінка конфігу- } \\
\text { рації сегмента } \\
\text { виробництво } \\
\text { сталі сталевого } \\
\text { (чорний) прокату } \\
\text { на 2020-2021 } \\
\text { роки } \\
\text { «майбутнє» }\end{array}$} \\
\hline & Інтервал змін & $\begin{array}{c}\text { Середнє значення; } \\
\text { межі відхилень від } \\
\text { середнього, } \pm \%\end{array}$ & Оцінка & \\
\hline 1 & 2 & 3 & 4 & 5 \\
\hline \multicolumn{5}{|c|}{ 1. Основні показники сегмента виробництво сталі і сталевого (чорного) металопрокату } \\
\hline $\begin{array}{l}1.1 \text { Річний обсяг випуску сталі, } \\
\text { млн т }\end{array}$ & $27,2 \ldots 21,06$ & 24,$13 ;( \pm 12,7 \%)$ & 3 & 21,$1 ;( \pm 15,0 \%)$ \\
\hline $\begin{array}{l}1.2 \text { Річний обсяг випуску прокату, } \\
\text { млн т }\end{array}$ & $23,1 \ldots 18,4$ & 20,$75 ;( \pm 11,32 \%)$ & 3 & 18,$4 ;( \pm 12,0 \%)$ \\
\hline $\begin{array}{l}1.3 \text { Річний дохід продажу сталево- } \\
\text { го прокату, млн дол. }\end{array}$ & $11018 \ldots 8777$ & 9897,$5 ;( \pm 11,3 \%)$ & 3 & $\begin{array}{c}9900,0 \\
( \pm 12,0 \%) \\
\end{array}$ \\
\hline \multicolumn{5}{|c|}{ 2. Динаміка змін ринку за 5 років } \\
\hline 2.1. Виробництво сталі, \% & $+5,2 \ldots-17,1$ & $-5,95 ;( \pm 187,4 \%)$ & $\begin{array}{l}\mathrm{H}, \\
\text { спад }\end{array}$ & 0 \\
\hline 2.2. Виробництво прокату, \% & $+7,0 \ldots-20,6$ & $-6,8 ;( \pm 200,3 \%)$ & $\begin{array}{c}\mathrm{H}, \\
\text { спад }\end{array}$ & 0 \\
\hline $\begin{array}{l}\text { 3. Конкуренція цінова на націона- } \\
\text { льному ринку }\end{array}$ & $\begin{array}{l}\text { Україна, Китай, } \\
\text { РФ, Туреччина }\end{array}$ & $4 ;( \pm 0$ & $\mathrm{C}$ & без змін \\
\hline $\begin{array}{l}\text { 4. Конкуренція цінова на світовому } \\
\text { ринку }\end{array}$ & $\begin{array}{l}\text { Китай, РФ, } \\
\text { Туреччина }\end{array}$ & $3 ;( \pm 0 \%)$ & $\mathrm{C}$ & без змін \\
\hline $\begin{array}{l}\text { 5. Загальна частка споживачів, } \\
\text { п/п 5.1..5.7 не менше ніж } 85 \%\end{array}$ & $2,9 \ldots 4,7$ & 3,$9 ;( \pm 23,7 \%)$ & 3 & без змін \\
\hline 5.1. Усі підприємства металургії & $0,29 \ldots 0,49$ & 0,$39 ;( \pm 25,6 \%)$ & 3 & 0,$3 ;( \pm 25,0 \%)$ \\
\hline $\begin{array}{l}\text { 5.2. Машинобудування, металооб- } \\
\text { робка }\end{array}$ & $0,2 \ldots 0,26$ & 0,$23 ;( \pm 13,0 \%$ & 3 & 0,$2 ;( \pm 15,0 \%)$ \\
\hline 5.3. Будівництво & $0,04 \ldots 0,06$ & 0,$05 ;( \pm 20,0 \%)$ & 3 & 0,$05 ;( \pm 20,0 \%)$ \\
\hline 5.4. Транспорт і зв'язок & $0,024 \ldots 0,037$ & 0,$03 ;( \pm 21,7 \%)$ & 3 & 0,$03 ;( \pm 20,0 \%)$ \\
\hline 5.5. Паливна промисловість & $0,017 \ldots 0,034$ & 0,$025 ;( \pm 34,0 \%)$ & $\mathrm{H}$ & 0,$025 ;( \pm 30,0 \%)$ \\
\hline 5.6. Хімічна та нафтохімічна галузі & $0,014 \ldots 0,022$ & 0,$018 ;( \pm 22,2 \%)$ & 3 & 0,$02 ;( \pm 20,0 \%)$ \\
\hline 5.7. Електроенергетика & $0,012 \ldots 0,019$ & 0,$015 ;( \pm 23,3 \%)$ & 3 & 0,$015 ;( \pm 25,0 \%)$ \\
\hline 6. Напрям і величина інтеграції & \multicolumn{3}{|c|}{$\begin{array}{l}\text { 1. Вертикальна, Систем Кепітал Менеджмент. } \\
\text { 2. Вертикальна, «Інтерпайп». } \\
\text { 3. Вертикальна «Українська енергометалургійна } \\
\text { компанія». Усі інтегровані від виробництва сиро- } \\
\text { вини до продажу готової продукції }\end{array}$} & без змін \\
\hline 7. Диференціація продукції & \multirow{2}{*}{\multicolumn{3}{|c|}{ 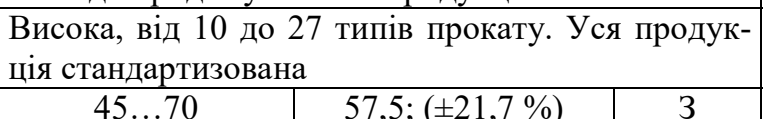 }} & без змін \\
\hline 8. Завантаження потужносте, \% & & & & без змін \\
\hline
\end{tabular}


Закінчення табл. 7

\begin{tabular}{|l|c|c|c|c|}
\hline \multicolumn{1}{|c|}{1} & 2 & 3 & 4 & 5 \\
\hline 9. Закон масштабу & $\begin{array}{c}\text { Витрати на одному } \\
\text { рівні }\end{array}$ & - & - & без змін \\
\hline 10. Закон досвіду & $\begin{array}{c}\text { Не є конкурентною } \\
\text { перевагою }\end{array}$ & - & - & без змін \\
\hline 11. Прибутковість галузі, \% & $\begin{array}{c}\text { Середня } \\
(-2 \ldots, 5) \%\end{array}$ & 3,$25 ;( \pm 38,46 \%)$ & Н & без змін \\
\hline $\begin{array}{l}\text { 12. Динаміка капіталовкладень, } \\
\text { млн дол./рік }\end{array}$ & $0,21 \ldots 0,77$ & 0,$49 ;( \pm 57,1 \%)$ & $\mathrm{H}$ & без змін \\
\hline
\end{tabular}

Джерело: [4; 9].

Висновки і пропозиції. 1. Представлено методологію процесу аналізу сегмента галузі чорної металургії України - виробництво сталі та сталевого (чорного) металопрокату на основі інтерактивного конфігураційного підходу (рис. 1), яка має теоретичну та практичну значущість.

2. Представлено стан конкуренції та кількісна оцінка восьми конкурентних сил ринкового середовища в умовах невизначеності (рис. 2), яке має теоретичну та практичну значущість.

3. Розроблено підсумкову таблицю оцінки стану основних параметрів ринкового середовища в сегменті галузі чорної металургії України - виробництво сталі та сталевого (чорного) металопрокату за 2014-2019 роки (табл. 6, 7), які мають теоретичну та практичну значущість.

4. Розроблений інтерактивний конфігураційний підхід має теоретичне та практичне значення, а також містить передумови подальшого розвитку та удосконалення.

\section{Список використаних джерел}

1. Глебова О. В., Мельникова О. Ю. Методы оценки рисков в условиях неопределенности. Иннов : электронный научный журнал. 2015. № 1(22). C. 7-10. URL: http://cyberleninka.ru/article/ n/metody-otsenki-riskov-v-usloviyah-neopredelennosti.

2. Гримашевич О. Н., Скасырский Н. С. Методы стратегического анализа в условиях неопределенности внешней среды. Вестник Саратовского государственного сочиальноэкономического университета. 2016. № 8. С. 19-22.

3. Занина Е. Г., Бородач Ю. В. Методика разработки анализа внешней среды предприятия в условиях неопределённости. Механизмы управления экономическими, экологическими и социальными процессами в условиях инновационного развития: материалы V Международной научнопрактической конференции (г. Алчевск, 28-29 ноября 2018 г.). Алчевск, 2019. С. 152-158.

4. Интернет-журнал Металл. URL: http:// www.readmetal.com.

5. Лящук А. В. Факторы стратегического планирования на предприятии. Научное обозрение. Экономические науки. 2018. № 1. С. 15-21.

6. Незаметдинов Н. Р. Проблемы выбора эффективных инвестиционных решений в условиях неопределённости. Иннов: электронный научный журнал. 2014. № 2(19). C. 13-15. URL: $\mathrm{http} / / / \mathrm{www}$.innov.ru/science/economy/problemy-vybora-effektivnykh-investitsionnykh-resheniy-v-usloviya.

7. Плеханов Н. А. Учёт неопределенности внешней среды (вероятностная постановка). Иннов : электронный научный журнал. 2015. № 2(23). C. 3-6. URL: http://cyberleninka.ru/article/n/ uchyot-neopredelennosti-vneshney-sredy-veroyatnostnaya-postanovka.

8. Портер М. Конкурентное преимущество: Как достичь высокого результата и обеспечивать его устойчивость / пер. с англ. 2-е изд. Москва : Альпина Бизнес Букс, 2006. 715 с.

9. Производство основных видов промышленной продукции по месяцам 2014-2019 годов. URL: http://www.ukrstat.org.

10. Франк Е. В., Машевская О. В. Стратегический менеджмент в условиях неопределённости внешней среды. Российское предпринимательство. 2013. Т. 14. № 1(223). С. 48-54.

11. Юрлов Ф. Ф., Андрианова И. Д. Постановка и анализ задач выбора эффективных решений в экономике в условиях неопределенности внешней среды. Современные проблемы науки и образования. 2014. № 6. URL: http://science-education.ru/ru/article/view?id=15798. 
ТЕОРЕТИЧНІ ПРОБЛЕМИ РОЗВИТКУ НАЦІОНАЛЬНОЇ ЕКОНОМІКИ

\section{References}

1. Glebova, O. V., Melnikova, O. Yu. (2015). Metody otsenki riskov v usloviiakh neopredelennosti [Methods of risk assessment in conditions of uncertainty]. Innov, 1(22), pp. 7-10. http://cyberleninka.ru/article/n/metody-otsenki-riskov-v-usloviyah-neopredelennosti.

2. Grimashevich, O. N., Skasyrskiy, N. S. (2016). Metody strategicheskogo analiza v usloviiakh neopredelennosti vneshnei sryedy [Methods of strategic analysis in an uncertain environment]. Vestnik Saratovskogo gosudarstvennogo sotsialno-ekonomicheskogo universiteta - Bulletin of Saratov State Socio-Economic University, 8, pp. 19-22.

3. Zanina, Ye. G., Borodach, Yu. V. (2019). Metodika razrabotki analiza vneshney sredy predpriyatiya $\mathrm{v}$ usloviyakh neopredelennosti [Methodology for developing an analysis of the external environment of an enterprise in conditions of uncertainty]. In Mekhanizmy upravleniia ekonomicheskimi, ekologicheskimi i sotsialnymi protsessami $v$ usloviyakh innovatsionnogo razvitiya: materialy V Mezhdunarodnoy nauchno-prakticheskoy konferentsii - Mechanisms of management of economic, ecological and social processes in the conditions of innovative development: materials of the VInternational scientific and practical conference (pp. 152-158).

4. Internet-zhurnal Metall. Readmetal. http://www.readmetal.com.

5. Lyashchuk, A. V. (2018). Faktory strategicheskogo planirovaniia na predpriiatii [Factors of strategic planning at the enterprise]. Nauchnoe obozrenie. Ekonomicheskie nauki-Scientific Review. Economic Sciences, 1, pp. 15-21.

6. Nezametdinov, N. R. (2014). Problemy vybora effektivnykh investitsionnykh reshenii v usloviiakh neopredelennosti [Problems of choosing effective investment solutions in conditions of uncertainty]. Innov, 2(19), pp. 13-15. http://www.innov.ru/science/economy/problemy-vyboraeffektivnykh-investitsionnykh-resheniy-v-usloviya/.

7. Plekhanov, N. A. (2015). Uchyet neopredelennosti vneshnei sredy (veroiatnostnaia postanovka) [Accounting for environmental uncertainty (probabilistic statement)]. Innov, 2(23), pp.3-6. http://cyberleninka.ru/article/n/uchyot-neopredelennosti-vneshney-sredy-veroyatnostnaya-postanovka.

8. Porter, M. (2006). Konkurentnoe preimushchestvo: Kak dostich vysokogo rezultata $i$ obespechivat ego ustoychivost [Competitive advantage: how to achieve a high result and ensure its sustainability] ( $2^{\text {nd }}$ ed). Alpina Biznes Buks.

9. Proizvodstvo osnovnykh vidov promyshlennoy produktsii po mesyatsam 2014-2019 godov [Production of the main types of industrial products by months of 2014-2019]. http://www.ukrstat.gov.ua. http://www.ukrstat.org.

10. Frank, Ye. V., Mashevskaya, O. V. (2013). Strategicheskiy menedzhment v usloviyakh neopredelennosti vneshney sredy [Strategic management in an uncertain environment]. Rossiiskoe predprinimatelstvo - Russian entrepreneurship, 14(1(223)), pp. 48-54.

11. Yurlov, F. F., Andrianova, I. D. (2014). Postanovka i analiz zadach vybora effektivnykh reshenii $\mathrm{v}$ ekonomike $\mathrm{v}$ usloviiakh neopredelennosti vneshnei sredy [Formulation and analysis of problems of a choice of effective solutions in the economy with uncertainty in the external environment]. Sovremennye problemy nauki i obrazovaniia - Modern problems of science and education, 6. http://science-education.ru/ru/article/view?id $=15798$.

Байгушев Володимир Володимирович - кандидат технічних наук, докторант кафедри фінансів та економічної безпеки, Дніпровський національний університет залізничного транспорту імені академіка В. Лазаряна (вул. Лазаряна, 2, м. Дніпро, 49010, Україна).

Байгушев Владимир Владимирович - кандидат технических наук, докторант кафедры финансов и экономической безопасности, Днепровский национальный университет железнодорожного транспорта имени академика В. Лазаряна (ул. Лазаряна, 2, г. Днепр, 49010, Украина).

Baigushev Vladimir - PhD of Technical Sciences, Doctoral Student of the Department of Finance and Economic Security, Dnipro National University of Railway Transport named after Academician V. Lazarian (2 Lazarian Str., 49010 Dnipro, Ukraine).

E-mail: vlodimir.baigushev@rambler.ru

ORCID: http://orcid.org/0000-0002-1582-2723

Байгушев В. Формування інтерактивних конфігурацій стану ринкового середовища. Проблеми і перспективи економіки та управління. 2020. № 2 (22). С. 7-17. 